\title{
THE CONSTITUTION AS AN EXPERIMENT
}

\author{
Louis H. Pollak $\dagger$
}

I.

In referring to the Constitution as an experiment, I have in mind two things. One is that our free institutions are always in the process of becoming. The other is that these institutions are always at risk. We had best not lose track of this next year, when all will be flags and rhetoric, or we shall wholly miss the point of why, for the two hundredth time, we will be complying with John Adams' injunction to Abigail, in a letter home from Philadelphia, on July 3, 1776:

[T] he day of deliverance ... ought to be solemnized with pomp and parade, with shows, games, sports, guns, bells, bonfires, and illuminations, from one end of this continent to the other, from this time forward, forevermore.

You will think me transported with enthusiasm, but I am not. I am well aware of the toil, and blood, and treasure, that it will cost us to maintain this declaration, and support and defend these States. Yet, through all the gloom, I can see the rays of ravishing light and glory. ${ }^{1}$

On the eighty-fifth anniversary of Independence, in 1861, the pomp and parade were muted. And so Lincoln acknowledged as he addressed the special session of Congress convened to cope with rebellion: "Our popular government has often been called an experiment. Two points in it our people have already settled-the successful establishing and the successful administering of it. One still remains-its successful maintenance against a formidable internal attempt to overthrow it."2

$\dagger$ Albert M. Greenfield Professor of Human Relations and Law, University of Pennsylvania. A.B. 1943, Harvard University; LL.B. 1948, Yale University. Member, New York and Connecticut Bars. This Article was delivered at the University of Pennsylvania on March 4,1975, as the second in a series of Presidential Lectures sponsored by University President Martin Meyerson.

19 The Works of John Adams 420 (C. Adams ed. 1854).

${ }^{2}$ The Speeches of Abraham Lincoln 337 (Lincoln Centenary Ass'n 1908). The special session of Congress was convened on July 4; but President Lincoln did not address Congress until July 5th. 
Years of bloody fighting followed. More battle deaths than the world had ever known. But the Union armies persevered. And, by the start of his second term, the President had grounds for confidence that the end of the war was in sight. Yet in his Second Inaugural-one hundred and ten years ago today-he contented himself with observing that the "progress of our arms, upon which all else chiefly depends . . . is, I trust, reasonably satisfactory and encouraging to all. With high hope for the future, no prediction in regard to it is ventured." 3 No prediction-yet, as the weary leader called on his countrymen "to finish the work we are in" and "to bind up the nation's wounds," 4 he surely felt that his generation had at last replicated the nation's original experiment, answering for their time the question he had posed at Gettysburg, whether a "nation, conceived in liberty, and dedicated to the proposition that all men are created equal . . . can long endure."5

II.

"With high hope for the future ...."We are now that future. During the past two years, it has fallen to our generation to deploy our constitutional processes to the full in order to restrain what, in Lincoln's phrase, can fairly be described as "a formidable internal attempt to overthrow" those processes.

We have been successful, in the sense that the corrupt chief leaders of the regime-and finally the President they so loyally served-have fallen from office and influence and esteem. All this came about-with powerful initial impetus from the press -through the confluent, and occasionally inconsistent, endeavors of judges, prosecutors, grand juries, and Senate and House committees. Ultimately decisive was revival of the moribund constitutional mechanism called impeachment.

If we measure these processes by the result-the resignation of a President who willfully dishonored his high office, to the detriment of his fellow-citizens-we can say, with gratification, that the constitutional experiment works in our time. That is, I think, the general assessment. But to the extent that this assessment implies confidence that impeachment is now established as an apt safeguard against future executive trespasses, I think

\footnotetext{
3 Id. 409.

+Id. 411 .

5 Id. 368.
} 
some important qualifications are in order. Taking as my text the three articles of impeachment proposed by the House Judiciary Committee, and the two rejected by that Committee, I shall try to explain my misgivings.

The first two impeachment articles will require little discussion: The first article refers specifically to the event which gave "Watergate" its name-the June 17, 1972 "unlawful entry of the headquarters of the Democratic National Committee" by "agents of the Committee for the Re-election of the President"- and then charges that "Richard M. Nixon, using the powers of his high office, engaged personally and through his subordinates and agents, in a course of conduct or plan designed to delay, impede, and obstruct the investigation of such unlawful entry ...."6

The second article is broader than the first, charging that the President "repeatedly engaged in conduct violating the constitutional rights of citizens, impairing the due and proper administration of justice and the conduct of lawful inquiries, or contravening the laws governing agencies of the executive branch and the purposes of these agencies." The attendant specifications cover many matters-politically motivated tax audits; wiretapping of government officials and reporters; efforts to sabotage the procedural rights of Daniel Ellsberg, a defendant in a federal criminal prosecution; and a host of misuses of, interferences with, and failures to inform, various federal investigative and prosecuting agencies.

A number of the acts charged in the first two articles probably constitute statutory crimes. Others may not. But, whether crimes in the conventional sense or not, they surely are, individually as well as in the aggregate, "high Crimes and Misdemeanors" within the meaning of the impeachment clause. For that clause, as Raoul Berger has demonstrated in his exhaustive study of impeachment, comprehends gross abuses of official power whether or not triable in an ordinary criminal prosecution. ${ }^{8}$

My concern about the first and second articles goes not to their soundness in law. My concern is of a very different sort. With break-in discovered, CREEP responsibility established, and

6120 Cong. Rec. 8967 (daily ed. Aug. 22, 1974).

id.

${ }^{8}$ R. Berger, Impeachment: The Constitutional Problems 53-102 (1973). 
White House complicity and cover-up suspected, Mr. Nixon would, I think, still be in the Oval Office today had he not indulged that curious passion for oral immortality which led him to tape, and not to destroy, his own wretched transgressions. With a friend like himself, Mr. Nixon had no need of Messrs. Ervin and Rodino, Dash and Doar, Cox and Jaworski. He was his own Special Prosecutor. What made the first two articles of impeachment such powerful weapons against a miscreant President was the President's obsessive insistence on incriminating himself. They would have availed little against a President not committed to his own destruction.

At this point someone may wish to remind me that the third article of impeachment recommended by the Committee was drawn in an exactly opposite sense. That article-far from being keyed to the President's evidence against himself-was precisely addressed to the President's noncompliance with a series of Committee subpoenas designed to elicit information thought to be relevant to the Committee's inquiry. Mr. Nixon, through his counsel, James St. Clair, had declined to produce a number of the items subpoenaed, and had justified his nonresponsiveness on the ground that the items were, in Mr. Nixon's judgment, within that category of presidential communications and other records which must be kept confidential for the proper working of the Presidency, a judgment which, it was further argued, the separation of powers committed to the President alone. In short, $\mathrm{Mr}$. Nixon was placing strong reliance on a constitutional history of presidential control over presidential papers which goes back to the beginning of the republic, but which has only in recent years been baptised "executive privilege."

In response to the President's constitutional defense, the Committee insisted on the constitutional authority and obligation of the House of Representatives to conduct those investigations required for the full exercise of the responsibility entrusted by the Constitution to the House alone- "the sole Power of Impeachment." Even Andrew Johnson had freely submitted to the House the information sought from him, in the only prior instance of a serious attempt to impeach a President. To permit Mr. Nixon to limit the House's inquiry by presidential fiat would, in the Committee's view, hopelessly undermine the very separation of powers upon which Mr. Nixon purported to rely. Wherefore, the Committee voted to recommend the impeachment of Mr. Nixon for defying the House subpoenas. 
To the extent that the question is whether Mr. Nixon's constitutional recalcitrance was justified, I think the answer is in the negative. Without fully subscribing to the thesis of Raoul Berger-who has written a major study of this matter, as of most others-that "executive privilege" is "a constitutional myth," I think Mr. Nixon's assertion of the confidentiality of the requested items fell far short of a persuasive demonstration that the pressing purposes of the House Judiciary Committee should give way. For such analogical value as it has, the Supreme Court's decision in United States $v$. Nixon ${ }^{10}$ certainly points in the same direction. That case, as you will recall, overruled the President's objections to a subpoena sought by the Special Prosecutor and granted by Judge Sirica, requiring the production of numerous items (including many tapes the President had previously published in edited form), which the President regarded as confidential but which the Special Prosecutor felt were required in order to prepare for the upcoming "cover-up" trial of Messrs. Mitchell, Haldeman, Erlichman and Mardian.

The unanimous opinion in United States $v$. Nixon was delivered by Chief Justice Burger. After some preliminary matters not pertinent here, the opinion addressed the President's claim that, consonant with the separation of powers, only the President could define the scope of a privilege necessary to the fulfillment of his constitutional duties. Not so, said the Chief Justice: ever since Marbury v. Madison-in which Chief Justice Marshall lectured Secretary of State Madison and President Jefferson on executive accountability to the law's demands-it has been the received understanding that, in Marshall's words, "[i]t is emphatically the province and duty of the judicial department to say what the law is." "Next, in assessing the claim of privilege, Chief Justice Burger began from the assumption, acquiesced in by the parties, that presidential communications are "presumptively privileged."12 But that presumptive privilege, when employed to attribute an undifferentiated confidentiality to presidential

9 R. Berger, Executive Privilege: A Constitutional Myth 1 (1974). Professor Berger's study of executive privilege has run into a certain amount of heavy weather. See Albert, Book Review, 74 Colum. L. Rev. 1360 (1974); Sofaer, Book Review, 88 Harv. L. Rev. 281 (1974); cf. Pollak, Book Review, Washington Post, June 30, 1974, § $\mathrm{F}$ (Book World) at 1 , col. 4 .

${ }^{10} 418$ U.S. 683 (1974).

11 Marbury v. Madison, 5 U.S. (1 Cranch) 137, 177 (1803).

12418 U.S. at 708. 
communications en masse (in contrast with, for example, what the Chief Justice referred to as "the President's interest in preserving state secrets,"13 an interest not at issue in United States $v$. Nixon), could not prevail against the constitutional obligation of the prosecution and the trial judge to insure access to all relevant evidence in a federal criminal trial. ${ }^{14}$

Decided on July 24, 1974, five days before the House Judiciary Committee began to vote on the draft articles of impeachment, United States $v$. Nixon was heavily relied on by proponents of the third article. As I have indicated, the precedent was one which seems to me analogically persuasive. But the precedent has a built-in limitation to which the Committee majority gave little apparent attention: In stating the parameters of what was decided, the Chief Justice was at pains to be explicit in reserving certain issues not decided; and one of these reservations might well have been taken as of considerable pertinence to the Committee's deliberations: "We are not here concerned with the balance . . . between the [President's] confidentiality interest and congressional demands for information . . .."15

But the real problem with the third article of impeachment was not whether the Committee's constitutional power of inquiry should have prevailed over the President's claim of constitutional privilege. The real problem was where that enormous constitutional confrontation should be resolved. The theory of the committee majority was that the House, by adopting the third article, should decide the question of the President's constitutional obligation in the House's favor, subject to Senate review at the impeachment trial. But the committee majority on the third article was only twenty-one to seventeen, far slimmer than the more-than-twothirds which voted the first two articles, ${ }^{16}$ and this portended

${ }^{13}$ Id. at 712 n. 19.

${ }^{14} \mathrm{Id}$. at 713 .

${ }^{15} \mathrm{Id}$. at $712 \mathrm{n} .19$. The Court's reservation was noted by at least ten of the seventeen Committee members who voted against the third article. 120 Cong. REc. 9099 n.20 (daily ed., Aug. 22, 1974).

16 The first two articles were voted on July 29, 1974, and the margins were 27-11 and 28-10, respectively. The third article was voted, and the two additional draft articles rejected, on July 30. Mr. Nixon's disclosure on August 5 of theretofore unrevealed conversations with Mr. Haldeman-the disclosure which precipitated Mr. Nixon's resignation four days later-appears to have led the eleven Committee members who had dissented from adoption of the first article to change their minds. Ten of the eleven, in one of the numerous separate statements of views which accompanied the Committee report when it was submitted to the House on August 22, expressed the view that the charges contained in the first article "in essence, if not in terms, may be taken 
substantial doubt that the article would have been sustained by two-thirds of the Senate, even assuming-what was itself doubtful - that a majority of the House would have approved it. Most, perhaps all, of the seventeen Committee members who were opposed to the third article felt that the House should not be asked, through the instrument of impeachment, to endorse the constitutional propriety of subpoenas issued in the House's name by the Committee. Instead, they felt that an adjudication of the propriety of the subpoenas should have been sought from the federal courts. Believing that the subpoenas were proper -and would have been so adjudged by courts seized of the issue-I agree.

The procedure preferred by the committee majority - under which the House (subject to Senate review) would have umpired the competition between its own constitutional claims and those of the President-is uncomfortably close to the prosecutorial pattern followed against Andrew Johnson a century ago. The Radical Republican Congress, over President Johnson's veto, passed the Tenure of Office Act, barring presidential removal of a cabinet member without Senate consent. Believing the act an unconstitutional infringement of presidential authority (a correct belief, as the Supreme Court determined over half a century later ${ }^{17}$ ), Johnson removed Secretary Stanton and was impeached by the House forthwith. Only by the margin of one vote less than the required two-thirds did the Senate fail to convict the President for carrying out his sworn constitutional duty. Arguably, there were valid grounds for impeaching Andrew Johnson, an implacable and effective non-implementer of Congress' reconstruction policy; ${ }^{18}$ but violation of the Tenure of Office Act was not one of them. The dangerous episode rooted itself deeply in national memory and so shaped our attitudes that, until Mr. Nixon's day, it was generally supposed that the impeachment clause was, as to Presidents, a dead letter.

In recalling the Andrew Johnson impeachment, I do not mean to suggest that in 1974 the House Judiciary Committee set its subpoenas as springes to catch $\mathrm{Mr}$. Nixon. The controversy

as substantially confessed by Mr. Nixon on August 5, 1974 . . ." 120 CoNG. Rec. 9059 (daily ed., Aug. 22, 1974).

17 . Myers $x$. United States, 272 U.S. 52 (1926).

${ }^{1 *}$ See Responses of the Presidents to Charges of Misconduct 111-12 (C. Vann Woodward ed. 1974). 
over the subpoenas was a genuine one. But, once the issue was drawn, for the prosecutor-House to have turned itself into the quasi-arbiter-House-declaring the superiority of its constitutional prerogatives to those of the President, and calling on the Senate to ordain condign punishment-would have been, in a word, unseemly. It would have smacked too much of being a judge in one's own cause-that fundamental impropriety which Coke condemned three-and-a-half centuries ago, in $D r$. Bonham's Case. ${ }^{19}$

I use the words "unseemly" and "impropriety," because I do not propose to argue that it is beyond the constitutional authority of either house of Congress to decide for itself, without recourse to the courts, whether a citizen's refusal to give evidence demanded by one of its committees is justified. Indeed, from the early days of the republic each house has asserted, and has on occasion exercised, the authority to commit recalcitrant witnesses to the custody of its sergeant at arms-a coercive aspect of the legislative power which derives from ancient Parliamentary practice. Happily, however, this form of legislative muscle-flexing has fallen into disuse. For well over a century, nonresponse to proper congressional questions has been a statutory crime triable in a federal court. And in such a trial the propriety of the congressional demand-its pertinence to a legitimate and welldefined investigative purpose, and the validity of constitutional or other privileges raised as matters of defense-is a question of law for the court.

And so I submit that the House Judiciary Committee would have been well advised to seek a judicial ruling that Mr. Nixon was constitutionally required to comply with the Committee subpoenas. Not, I hasten to add, by invocation of the criminal process against an incumbent President, but by seeking legislative authorization for a civil suit brought by the Committee against Mr. Nixon, asking a court order directing the defendant to comply-after the model of the Special Prosecutor's request for court enforcement of his subpoena which bore fruit in United States $v$. Nixon. If the Committee had proceeded in the manner outlined, and Mr. Nixon had defied a court order to produce the items subpoenaed by the Committee, impeachment, and conviction, would have followed swiftly and inexorably. Defiance

1977 Eng. Rep. 646 (K.B. 1610). Accord, VanAlstyne, The Third Impeachment Article: Congressional Bootstrapping, 60 A.B.A.J. 1199 (1974). 
of a court order was the one presidential offense which nobody would have tried to rationalize- $a$ fact apparently recognized at the last by Mr. Nixon himself: Wherefore his statement, a few hours after the Supreme Court's ruling in United States v. Nixon, that he would comply. Wherefore his desperate attempt, a few days later, to disclose and apologize for the damning dialogue not theretofore, but now at last judicially required to be, surrendered. Wherefore his resignation.

Stripped to its essentials, the argument of the majority of the House Judiciary Committee was that to permit a court to weigh the sufficiency of its subpoenas would entail conceding judicial authority to measure the outer limits of the impeachment power, thus compromising the power which the Constitution exclusively vests in the House to impeach and in the Senate to judge impeachments. Assuming that there is no judicial power to review a Senate judgment of guilt-an assumption I think probably correct, although a plausible contrary argument has been advanced ${ }^{20}$-I am nonetheless unpersuaded that court review of a House subpoena issued in aid of impeachment would unconstitutionally trammel the independence of the House and the Senate in determining what acts constitute "high Crimes and Misdemeanors," the constitutional phrase to which, by hypothesis, only the House and Senate can give a binding definition. It could with equal logic be argued, so it seems to me, that no court could monitor the questions asked and material subpoenaed by congressional committees investigating with a view to amending the Constitution, since (with one exception, the equal representation of states in the Senate) there is no limit to the amendability of the Constitution and hence, I suppose, no limit to what Congress could inquire into. ${ }^{21}$

\footnotetext{
${ }^{20}$ See R. BERGER, supra note 8 , at 103-21.

21 There were, of course, other arguments advanced by the committee majority for not seeking a judicial determination of the validity of the Committee's subpoenas; but most of the arguments seem makeweights. The notion that it would have been timeconsuming is not very compelling: the Senate Select Committee on Presidential Campaign Activities (the Ervin Committee) learned in 1973 that a special jurisdictional statute would be required if it were to sue to enforce its writs, Senate Select Committee v. Nixon, 366 F. Supp. 5 I (D.D.C. 1973), and such legislation was enacted quickly, without a veto. Act of Dec. 18, 1973, Pub. L. No. 93-190, 87 Stat. 736. But see Senate Select Committee v. Nixon, 370 F. Supp. 521 (D.D.C.), aff'd, 498 F.2d 725 (D.C. Cir. 1974). And the actual litigation of United States $v$. Nixon was accomplished most expeditiously. As to the committee majority's expressed concern that a lawsuit to enforce the Committee's subpoenas would be held to be a nonjusticiable "political question" touching on the unreviewable prerogatives of the House of Representatives, it would appear that the federal courts
} 
What I have just argued is, I am afraid, too much a lawyer's point-or, if you will, a debater's point-to do useful service before a human audience. Let me try one other tack, and with this I will close my discussion of the third article of impeachment. You will recall my pointing out that the proponents of the third article relied heavily on the Supreme Court's decision in United States $v$. Nixon, decided only a few days earlier. And you will also recall my agreeing that the decision was a persuasive -but merely a persuasive, hardly a conclusive-precedent. But let us assume, for purposes of argument, that United States $v$. Nixon had gone the other way. Let us assume, specifically, that the Court had acquiesced in Mr. Nixon's not wholly implausible claim that the separation of powers reserves to the President alone the decision whether materials in his custody can be turned over to another branch of government without prejudice to the President's fulfillment of his awesome constitutional responsibilities. If the proponents of the third article are to be taken at face value, they ought to be prepared to say that, if the Court had decided United States $v$. Nixon in the manner I have just supposed, such a decision would not have precluded the House Judiciary Committee-and thereafter the full House, and thereafter the Senate-from ruling that a presidential decision not to submit the subpoenaed items must yield to the better judgment of the Committee, on pain of impeachment. Yet we know that here theory and practice would have parted company. We know that even the Committee-let alone the full House, and the Senate-would not have so ruled; for they would have known that our institutions could not have coped with contrarieties of such magnitude. And the reason-a reason lodged deeper in our history and our folkways than any finely spun theory-why it is the Court's word, and not the word of the House or Senate, which would have stood against the world, is

might well be trusted to make up their own minds on matters which so clearly relate to judicial perceptions of the propriety of judicial action affecting the claims of the coequal branches of government. I submit, moreover, that in resolving this issue the federal courts would, very properly, regard a statute conferring jurisdiction on the courts to resolve a dispute between the House and the President as strong evidence that the reasons ordinarily impelling courts to exercise caution about intervening in matters affecting the other branches should, in this instance, be regarded as of limited weight. See text accompanying note 43 infra. For a very thoughtful analysis which gives greater weight to the justiciability problem, see Cox, Executive Prizilege, 122 U. PA. L. Rev. 1383, $1419-38$ (1974). 
that "[i]t is emphatically the province and duty of the judicial department to say what the law is."22

My view, then, is that the House Judiciary Committee was in error in judging itself to be the optimum tribunal to decide whether the President was obliged to submit certain required information to one of the houses of Congress. The question I now wish to consider is why the House Judiciary Committee felt itself not to be the right tribunal to decide whether information actually submitted to Congress, or to other government officials, was knowing falsehood. That question is posed by the two draft impeachment articles the Committee rejected.

One of these draft articles-that which alleged tax fraud, chiefly in connection with massive deductions claimed to flow from the gift of Mr. Nixon's vice-presidential papers to the Archives-need not detain us long. It may be-as some opponents of the draft article argued-that there was no sufficiently compelling evidence of Mr. Nixon's personal involvement; or that tax fraud, even by a President, is an essentially private crime, not an abuse of official power, and hence not an impeachable offense.

One might disagree with both of these positions, yet it would be hard to regard them as rationally untenable-particularly if one bears in mind that each article of impeachment must be weighed as an independent charge, one that would warrant removal of a President who has in all other respects governed himself and his country in exemplary fashion. In any event, tax fraud is a matter regularly open to judicial inquiry. Not, you will say, against an incumbent President, who is presumably immune from criminal prosecution while in office. True, but the Committee could reasonably have anticipated that, if one or more of the three articles of impeachment it had approved led to $\mathrm{Mr}$. Nixon's departure from office, and if the Special Prosecutor was persuaded that the evidence of personal culpability was stronger than was apparent to many of the Committee members, $\mathrm{Mr}$. Nixon would then be open to indictment. There was, that is to say, no basis for a prophecy that $\mathrm{Mr}$. Nixon, as a private citizen, would be beyond reach of the criminal process.

The draft article I want to discuss at greater length is one which charged a very different fraud: namely, that Mr. Nixon, supre.

22 Marbury צ. Madison, 5 U.S. (1 Cranch) 137, 177; see text accompanying note 11 
"on and subsequent to March 17, 1969, authorized, ordered, and ratified the concealment from the Congress of the facts and the submission to the Congress of false and misleading statements concerning the existence, scope and nature of American bombing operations in Cambodia in derogation of the power of Congress to declare war, to make appropriations and to raise and support armies, and by such conduct warrants impeachment and trial and removal from office." 23

In order properly to comprehend the draft article, and its disposition, I will take the liberty of refreshing your recollection about events many of us would prefer to forget. For most Americans, active awareness of Cambodia began with the monthlong "incursion" into Cambodia and Laos undertaken by Mr. Nixon in May of 1970. According to the Commander in Chief, the "incursion" was required militarily in order to protect American troops in neighboring Vietnam. And the military justification apparently also supplied the legal justificationtenuous as it was-for invading foreign countries without prior congressional approval. Left substantially unexplained was how this new military activity was likely to expedite fulfillment of the commitment Candidate Nixon made, when he accepted his party's nomination in the summer of 1968: "I pledge to you tonight that the first priority foreign policy objective of our next administration will be to bring an honorable end to the Vietnam war."24

For the people of Cambodia, the 1970 "incursion" by American infantry was simply a new phase of American military activity which had been going on-in the form of aerial attacks-ever since March of 1969, two months after Mr. Nixon took office. Few Cambodians could have known, and fewer still could have cared, that their then head of state, Prince Sihanouk, was said (at least in Washington) to have given his secret non obstat to the American planes. At all events, the pre-"incursion" American war in Cambodia was unknown to most Americans: The only Americans privy to the enterprise were a few officials in the White House, the Pentagon and the State Department; a tight cadre of trusted members of Congress; and the bomber crews who did the dirty work. The scenario, tersely recited in the House Judiciary Committee's Report, was this:

${ }^{23} 120$ Conc. Rec. 9027 (daily ed. Aug. 22, 1974).

${ }^{24}$ T. White, The Making of the President 1968, at 255 (1969). 
On February 11, 1969, the President received the initial request to institute the bombing from his military advisors. On March 17, 1969, after a series of National Security Council meetings, the President approved the request and directed that the operation be undertaken under tight security.

On March 18, 1969, the bombing of Cambodia commenced with B-52 strikes under the code name MENU OPERATION. These strikes continued until May 26, 1970, almost one month after the American incursion into Cambodia. The operational reports prepared after each mission stated that these strikes had taken place in South Vietnam rather than in Cambodia. ${ }^{25}$

This was the factual essence of the charge made by the draft article of impeachment on Cambodia. There is not now and never has been any serious dispute about the facts, nor even about the deliberateness of the effort of high level military and civilian officials to mislead Congress (apart from the White House's few selected confidants) and the people. Whether any of this production and distribution of untruths was criminal is not clear. I would only say that the question is not, in my mind, entirely resolved in the negative by the luminous opinion submitted by George S. Brown to the Senate Armed Services Committee in July of 1973, shortly after the Government had at last acknowledged the theretofore concealed bombings of 1969 and 1970: "For falsification to constitute an offense," wrote General Brown, then Air Force Chief of Staff, "there must be proof of 'intent to deceive.' This is a legally prescribed element of the offense and is negated when the report is submitted in conformity with orders from a higher authority in possession of the true facts." 26 General Brown's theory, for whatever it is worth, would appear to insulate everyone up to, but not including, the President.

However, the immediate question is not whether this elaborate deception was in any respects criminal. The immediate question is why the House Judiciary Committee did not regard

${ }^{25} 120$ ConG. Rec. 9027 (daily ed. Aug. 22, 1974).

${ }^{26}$ Statement of General George S. Brown, quoted in A. Schlesinger, The Imperial Presidency 357 (1974). 
as impeachable the "cover-up," if I may use the term, of a major military campaign waged clandestinely in a foreign land.

The Committee might have felt that charges that a President misrepresented military events were not a new phenomenon. The recriminations about the Tonkin Gulf Resolution-did President Lyndon Johnson overstate the threat to American forces? and did the administration thereafter read into the Resolution, advertently or otherwise, a wider war-making power than Congress meant to confer?-were fresh in the Committee's memory. And those Committee members with an ear to history could recall the obscure Whig Congressman from Illinois who charged that American troops were on Mexican soil-not, as President Polk claimed, on American soil-when the Mexican War began.

But, as we shall see, the Committee's rejection of the draft article apparently did not turn on the question whether $\mathrm{Mr}$. Nixon had directed his air force generals to lie to Congress and the people. It seems to have turned, instead, on the constitutional question which underlies the lies-to what extent does a President require congressional authorization to wage a foreign war? That, indeed, was the underlying question which gave substance to the Whig challenge to Polk. The Whigs felt that a war begun by American troops on foreign soil without congressional authority was a "war . . . unnecessarily and unconstitutionally commenced by the President."27 Because Congressman Lincoln and his fellow Whigs were unable to persuade Congress and the nation that the fighting began in Mexico, their challenge to the constitutionality of Polk's war was unavailing. But the point of law remained.

The point of law is this: The Constitution, as we all know, designates the President as Commander in Chief, but it also vests in Congress the power to declare war, to raise armies and navies, and to appropriate funds for their support. As Commander in Chief, the President is plainly empowered, and indeed obligated, to commit the forces under his command against invasion (as President Polk asserted he was doing) and against rebellion (as Presidents Washington and Lincoln both did) without asking leave of Congress. But a war waged outside American territory would seem, under the Constitution, to require congressional approval. ${ }^{28}$

27 The Speeches of Abraham Lincoln, supra note 2, at 12.

${ }^{28}$ There is of course a large and growing contemporary literature on the war power. 
Such congressional approval need not be an enactment calling itself, in haec verba, a "declaration of war," provided that it is legislative action which shows with adequate clarity that the House and Senate have given deliberate support to the President's military endeavor. Such congressional support may be evidenced at the outset - an example of this, albeit an ambiguous one, being the Tonkin Gulf Resolution, characterized by Under Secretary of State Katzenbach as the "functional equivalent" of a declaration of war with respect to the Vietnam conflict. $^{29}$ Such congressional support is perhaps more often evidenced after the fact, through continuing appropriations-as it long was in Vietnam; and as it also was, albeit grudgingly, in Korea, where President Truman neither sought nor received any congressional mandate at the outset of the conflict. ${ }^{30}$

It is of course the fact that throughout our history there have been scores of American military interventions outside our territory which were neither authorized nor ratified by Congress. Happily, most of these were relatively minor engagements-defending American troops or civilians stationed ab-

See Berger, War-Making by the President, 121 U. PA. L. REv. 29 (1972); Lofgren, WarMaking Under the Constitution: The Original Understanding, 81 YALE L.J. 672 (1972); Rostow, Great Cases Make Bad Law: The War Powers Act, 50 Tex. L. Rev. 833 (1972); Van Alstyne, Congress, the President, and the Power to Declare War: A Requiem for Vietnam, 121 U. PA. L. Rev. 1 (1972). See also Henkin, Foreign Affairs and the Constitution 100-04 (1972).

${ }^{29}$ Hearings on S.R. 151 Before the Senate Comm. on Foreign Relations, 90th Cong., Ist Sess. 82-93 (1967).

${ }^{30}$ The commitment of forces in Korea (a commitment which-in contrast with our entry into Vietnam-I think was, on the merits, the right course of action) drew its legal justification in substantial part from our treaty obligations as a signatory of the United Nations Charter, the Security Council having called on member nations to assist South Korea in repelling the invading armies which had crossed the border from North Korea. In retrospect, I have come to the conclusion that a treaty is not a constitutionally effective method of vesting the decision for war in the President. Even if one takes the view, of which I have doubts but not to the point of certainty, that Congress can delegate its share of the decision to the President under carefully defined circumstances, delegation by treaty seems inadmissible because it wholly excludes the House of Representatives from the decisional process. See Van Alstyne, supra note 28 , at 15 . Although I am inclined to the view that the Korean war may be taken as having been ratified by Congress through subsequent appropriations, in hindsight I am persuaded that Senator Vandenberg was right in concluding that President Truman made a "great mistake" in not asking express congressional endorsement of his decision to commit forces to Korea. See A. Schlesinger, supra note 26 , at 134 . Thus, I find myself compelled to file a reluctant traverse to the claim of Dean Acheson (who, as Secretary of State, was President Truman's chief adviser both as to the commitment of forces under United Nations auspices and as to the disutility of a presidential request that Congress endorse the decision): "There has never, I believe, been any serious doubt-in the sense of nonpolitically inspired doubt-of the President's constitutional authority to do what he did." D. Acheson, Present at the Creation 414 (1969). Cf. Letter from L.S. Lipson to L.H. Pollak, April 2, 1975, on file with the author. 
road, resisting pirates, and the like. They do not, in my judgment, confirm a generalized authority in the Commander in Chief to take, independently of Congress, any actions, anywhere in the world, which, he may feel, conduce to the security of American military forces-an authority on the basis of which both the covert bombing of Cambọdia and the overt "incursion" were justified. As Professor Schlesinger has pointed out, the crucial constitutional analysis was made by Lincoln in a letter to his law partner, Billy Herndon, in which he challenged Herndon's acquiescence in broad presidential power to initiate hostilities beyond our borders: "Allow the President to invade a neighboring nation, whenever he shall deem it necessary to repel an invasion ... and you allow him to make war at pleasure. Study to see if you can fix any limit to his power in this respect." The power to make war, Lincoln added, was the power which "our convention understood to be the most oppressive of all kingly oppressions; and they resolved to so frame the Constitution that no one man should hold the power of bringing this oppression upon us. But your view destroys the whole matter, and places our President where kings have always stood."31

Having in mind this capsule summary of some of the legal issues relating to presidential authority to wage foreign wars, we can now return to the problem of Cambodia.

The secret bombing of Cambodia in 1969 and 1970 was not officially acknowledged until July of 1973. By then American planes were again engaged in bombing Cambodia, and indeed had been for many months, but this time no secrecy surrounded the enterprise. However, by March of 1973 the last Americans had finally been repatriated from neighboring Vietnam, which appeared to put an end to the administration's rationale-the Billy Herndon rationale, updated and projected halfway around the world-for attacking enemy enclaves in country $A$ which are regarded as a threat to American forces in country $B .{ }^{32}$ Con-

${ }^{31}$ Letter from Abraham Lincoln to William Herndon, Feb. 15, 1848, in A. SCHLesinger, supra note 26 , at 42-43 (emphasis supplied).

32 Professor Schlesinger, after discussing the inadequacies of the various quasiarguments advanced by administration spokesmen for the post-March 1973 bombing of Cambodia, adds this paragraph which lawyers-and their fellow citizens-might well ponder:

All this fiddling, one feels, was by the way. The Deputy Assistant Secretary of State for Far Eastern Affairs probably put the administration view more bluntly when he was asked about the President's legal authority at a congressional briefing. "It is interesting you should ask me about that," he said. "I have got a couple of lawyers working on it." After a moment he added, "The justifica- 
gress, in June, legislated an immediate cutoff of the use of theretofore appropriated funds in connection with military operations in Cambodia;33 but Mr. Nixon vetoed the bill. ${ }^{34}$ Unable to override the veto, the congressional majority immediately enacted an August 15 cutoff, which Mr. Nixon signed into law on July $1 .{ }^{35}$ However, Congresswoman Holtzman, who had objected to the August 15 compromise, joined with several private citizens in a suit to direct Secretary of Defense Schlesinger to discontinue Cambodian military operations forthwith. The burden of the plaintiffs' case was that a congressional majority demonstrably wanted the Cambodian war ended back in June, and that $\mathrm{Mr}$. Nixon had no constitutional authority to continue to wage war simply because the congressional majority was not large enough to override a veto. The plaintiffs prevailed in the lower court; but the Court of Appeals for the Second Circuit reversed, holding that the matter was a "political question" and also that none of the plaintiffs, including Congresswoman Holtzman, had that clearly identifiable individual interest in the litigation which lawyers call "standing." 36

In the fall of 1973, Congress passed the War Powers Resolution. ${ }^{37} \mathrm{Mr}$. Nixon vetoed the Resolution; the veto message characterized the enactment as not merely an unwise but an unconstitutional attempt to limit the President in the exercise of his powers as Commander in Chief. ${ }^{38}$ Congress overrode the

tion is the re-election of President Nixon." "By that theory," the Washington Post commented, "he could level Boston."

Id. 198.

${ }^{33}$ The immediate cutoff was initially passed by the House on May 10, 1973, 119 Cong. Rec. 3598 (daily ed. May 10, 1973) and by the Senate on May 31, id. 10123 (daily ed. May 31, 1973), but the compromise measure was not adopted by the House until June 25, id. 5274-75 (daily ed. June 25, 1973) and by the Senate until June 26, id. 12057 (daily ed. June 26, 1973).

${ }^{34} 119$ Cong. Rec. 5486 (daily ed. June 27, 1973).

${ }^{35}$ Act of July 1, 1973, Pub. L. No. 93-50, tit. III, § 307, 87 Stat. 99, 129; see Statement by the President on Signing Supplemental and Continuing Appropriations Bills, 9 Weekly Compilation of Presidential Documents 881 (July 9, 1973).

${ }^{36}$ Holtzman v. Schlesinger, 484 F.2d 1307 (2d Cir. 1973), rev'g 361 F. Supp. 553 (E.D.N.Y. 1973). The Government's appeal to the Court of Appeals had the effect of staying enforcement of the injunction issued by the District Court directing Secretary Schlesinger to stop the war. The plaintiffs' unavailing attempts to reinstate the injunction pending appeal are reflected in the series of opinions in Holtzman v. Schlesinger, 414 U.S. 1304 (Marshall, Circuit Justice), 1316 (Douglas, Circuit Justice), 1321 (Marshall, Circuit Justice) (1973).

${ }^{37}$ H.J. Res. of Nov. 7, 1973, Pub. L. No. 93-148, 87 Stat. 555 (codified at 50 U.S.C.

$\$ \S 1541$ et seq. (Supp. III, 1973)).

${ }^{38} 119$ Cong. Rec. 20093 (daily ed. Nov. 7, 1973). 
veto. ${ }^{39}$ The Resolution requires the President to advise Congress within forty-eight hours if, in the absence of a declaration of war, he introduces American armed forces into the territory, airspace or waters of a foreign country (except for training, or supply, or replacement), or "into hostilities or into situations where imminent involvement in hostilities is clearly indicated by the circumstances." 40 The Resolution further provides that the President must withdraw such forces within sixty days unless Congress in the interim declares war, enacts a "specific authorization" for the continued presence of the forces, or extends the sixty-day period. The President can lengthen the sixty days by an additional thirty days if he certifies that the safety of American forces so requires. But without regard for the sixty-day timetable, "at any time that United States Armed Forces are engaged in hostilities outside the territory of the United States, its possessions and territories without a declaration of war or specific statutory authorization, such forces shall be removed by the President if the Congress so directs by concurrent resolution," ${ }^{41}$ a form of legislative action not subject to veto.

It was against this background that the House Judiciary Committee, in July of 1974, rejected the draft article on Cambodia. The majority's views, as summarized in the Committee's report, were these:

The Committee did not agree to the article for a variety of reasons. The two principal arguments in opposition to it were that President Nixon was performing his constitutional duty in ordering the bombing and that Congress had been given sufficient notice of the bombing. Several Members stated that the President as Commander-in-Chief was acting to protect American troops and that other Presidents had engaged in similar military activities without prior Congressional consent. Examining the bombing of Cambodia from the perspective of Congressional responsibility, the opponents of the Article concluded that, even if President Nixon usurped Congressional power, Congress shared the blame through acquiescence or ratification of his actions. They stated that the President had provided suf-

${ }^{39}$ The Senate and the House overrode the veto on November 7, 1973. Id. 20115-16; id. 9661 .

40 War Powers Resolution § 4(a)(1), 50 U.S.C. § 1543(a)(1) (Supp. III, 1973).

${ }^{41}$ Id. § 5(c), 50 U.S.C. $\$ 1544$ (c) (Supp. III, 1973). 
ficient notice of the military actions to Congress by informing key Members. Finally, they said that the passage of the War Powers Resolution in 1973 mooted the question raised by the Article. ${ }^{42}$

The most striking aspect of the paragraph just quoted is the discontinuity between the charge-that Mr. Nixon directed a scheme to hide a massive military campaign from Congress-and the grounds assigned for dismissing the charge. In effect the rationale of dismissal was not that the charge was untrue but that it did not state an impeachable offense. And the Committee's reasoning appears to have taken the following course: A President is constitutionally entitled to commit American troops to combat in foreign country $A$ in order to protect American troops located in foreign country $B$. To the extent that Congress, under the Constitution, shares with the President the power to decide to make war, Congress can exercise that power not only through prior consent but also through retroactive approval. With respect to the Cambodian bombing, the confidential briefing of a few "key" Representatives and Senators was the "functional equivalent" of retroactive approval by Congress. It is here, of course, that the reasoning, tenuous as it is, breaks down. Notice to a few influential members-even in an institution as shackled to seniority as Congress has been-cannot rationally be thought to bind the minds and consciences of five hundred others on the most fateful issues a democratic legislative assembly can decide.

Surely the key to the Committee's rejection of the charge based on the Cambodian bombing is to be found in the notion that the War Powers Resolution "mooted" the charge. It hardly needs argument that the wrong-if wrong it was, as I conceive it to be-involved in the deliberate misleading of Congress was not cured by the passage of a law specifying the modes of informing Congress when future Presidents make comparable military decisions. If, on the other hand, Mr. Nixon had no obligation to speak truth to the whole Congress about Cambodia, because he had no constitutional need for anything more than the nondisapproval of the few senior legislators his generals gave briefings to, then the Committee was right not to press the draft article of impeachment. But under that expansive view of presidential war-making authority, the War Powers Resolution would 
appear to be-as Mr. Nixon argued in his veto message-an unconstitutional infringement on the authority of the Commander in Chief.

In fact, of course, the Committee's rejection of the Cambodian bombing charge was neither an acquittal of Mr. Nixon nor an invalidation of the War Powers Resolution. It was an act of equivocation by Congressmen (confronted with a political crisis requiring swift action) who were unable to find in the doctrinal quagmire which surrounds the war-making power a standard clear enough to measure whether Mr. Nixon, secretly bombing Cambodia in the asserted exercise of his constitutional prerogative, had undermined the constitutional prerogative of Congress. Had the committee majority so articulated the problem, and pointed out mechanisms which could be counted on to resolve these constitutional dilemmas in the future, I would have applauded. For that would have betokened the sort of disciplined restraint I think was lacking when the committee majority, in voting up the third article of impeachment, chose to pit its constitutional claims against the President's and to judge between them.

Unfortunately, one of the principal reasons war power issues have remained so cloudy, notwithstanding our long experience in war-making, has been the difficulty of moving these issues from the level of ad hoc political dispute to the level of generalizable judicial discourse. The unwillingness of the Court of Appeals to consider Congresswoman Holtzman's law suit against Secretary Schlesinger-on the ground that it presented a "political question," and that the plaintiffs lacked "standing"-illustrates the difficulty. Nor is the difficulty certain to be obviated by the War Powers Resolution, for that Resolution contains no provision for enforcement. If a future President disagreed with members of Congress on the applicability of the Resolution in a particular instance-if, for example, he construed a law as a "specific authorization" for the continued commitment of forces abroad, and the congressional leadership took a contrary view-the nation would be at impasse. So too if a future President espoused Mr. Nixon's view that the Resolution itself is unconstitutional. To try these fundamental issues of distribution of power between Congress and the President via the impeachment process would, for reasons I have developed earlier, not be an optimal mode of adjudication. But if there is no other mode of adjudication, we would be perilously close to confessing in- 
stitutional bankruptcy as to that part of the Constitution which sought to bring within the rule of law what Lincoln, recalling the views of the framers, referred to as "the most oppressive of all kingly oppressions."

By amendment to the War Powers Resolution, Congress may be able to put the Constitution less at risk. I suggest a provision which would come into play in the event of the sort of impasse between Congress and the President which I have hypothesized. The provision would authorize Congress, by concurrent resolution, to bring suit in its own name in a federal court in Washington to compel the President to comply with whichever provisions of the Resolution lay in issue between the two branches. Congress could not, of course, compel the federal courts to accept jurisdiction; it is up to the courts, and ultimately the Supreme Court, to determine whether a particular form of law suit is a justiciable "case" or "controversy" within the meaning of the Constitution. But it is reasonable to suppose that the Supreme Court, in deciding whether such a law suit was a "political question" or was justiciable, would pay great heed to the constitutional imperatives moving Congress to seek judicial arbitrament of the great issues in dispute between Congress and the President. ${ }^{43}$

\section{III.}

With a view to assessing impeachment as a curb on Presidents, I have examined at some length the disposition by the House Judiciary Committee of the charges made against Richard Nixon. Those charges (the question of tax fraud aside) are clearly addressed to the exercise by Mr. Nixon of his public responsibilities. And they go to the first values and central workings of a free society. Their implication might have been better

${ }^{43}$ There is some judicial precedent for recognizing that Congress as an entity may have a judicially cognizable interest in constitutional litigation in which the powers of Congress and the President are in opposition. In Myers v. United States, 272 U.S. 52 (1926), the plaintiff sued in the Court of Claims to recover his unpaid salary as a postmaster, an office from which he had been removed by the President notwithstanding a statute which forbade presidential removal of that category of federal employees without the consent of the Senate. The United States, as defendant, contended that the statute was an unconstitutional limitation on presidential power. The Supreme Court invited the Senate, as amicus curiae, to present its case for the constitutionality of the challenged law; Senator George Wharton Pepper represented the Senate in what turned out to be a losing cause. Compare Myers, supra, with United States v. Lovett, 328 U.S. 303 (1946) and Powell v. McCormack, 395 U.S. 486 (1969). 
sensed had they been retranslated from lawyer's English back into what might be called anti-king's English-the phrases which Jefferson used, in the Declaration, to arraign George III: "He has obstructed the Administration of Justice. . . . He has affected to render the Military independent of and superior to the Civil Power."

My conclusion is that the House Judiciary Committee, in refurbishing the instrument of impeachment, has gone far toward reimposing legal restraints on the Presidency, but that the task is far from complete. The Committee coped well with $\mathrm{Mr}$. Nixon's domestic trespasses-with the important caveat that the Committee almost overreached in seeking to decide for itself that its writ is sovereign. But the Committee fumbled badly in its ambiguous handling of $\mathrm{Mr}$. Nixon's self-aggrandizement as Commander in Chief. Given the murky state of war power doctrine, it is certainly arguable that the Cambodian outrage, and the systematic lying to Congress and the people which facilitated it, were not impeachable offenses. But it is profoundly unfortunate that the Committee left the record in such a state as to suggest to the world, and to the future, that Mr. Nixon's sleight of hand with the most terrible of his powers was found by the Committee to be, for the most part, above constitutional reproach.

However, if the Committee meant-as I take it to have meant-not to condone the secret bombing of Cambodia but to declare it beyond the Committee's competence to judge, that conclusion, which I would have regarded as a wholly permissible one, should have been clearly formulated. Taking the deed for the word, I have suggested that there may be a way in which Congress, by supplement to the War Powers Resolution, can enlist the courts in building auxiliary constitutional defenses against future presidential abuses of the war power.

\section{IV.}

Twice he took the prescribed oath to "preserve, protect and defend the Constitution of the United States." But he does not seem to have understood, until the last days, that the President too-the President even more than the rest of us-is subject to its commands. "The Constitution of the United States," said the Supreme Court a century ago in Ex parte Milligan, ${ }^{44}$ "is a law for 
rulers and people, equally in war and in peace, and covers with the shield of its protection all classes of men, at all times, and under all circumstances." 45

Wholesale subversion of the Presidency, by the President, was, until our time, unprecedented. But it was not unforeseen. In Milligan the Court also said: "This nation . . . has no right to expect that it will always have wise and humane rulers, sincerely attached to the principles of the Constitution. Wicked men, ambitious of power, with hatred of liberty and contempt of law, may fill the place once occupied by Washington and Lincoln ..." 46 For this reason, so the Court observed, and for the related reason that liberty is most at risk in time of war, the founders of the nation "secured the inheritance they had fought to maintain, by incorporating in a written constitution the safeguards which time had proved were essential to its preservation." 47

Confronted in our time by a challenge without precedent, the Constitution has prevailed. We have reason to be grateful. We have need to be vigilant. We have grounds to be hopeful - guardedly hopeful-that the experiment will continue to work. The grounds for hope are those expressed one hundred and seventy-four years ago this day, by Jefferson, when he first took the presidential oath:

I know, indeed, that some honest men have feared that a republican government cannot be strong; that this government is not strong enough. But would the honest patriot, in the full tide of successful experiment, abandon a government which has so far kept us free and firm, on the theoretic and visionary fear that this government, the world's best hope, may, by possibility, want energy to preserve itself?

I trust not. I believe this, on the contrary, the strongest government on earth.

I believe it is the only one where every man, at the call of the law, would fly to the standard of the law; would meet invasions of the public order as his own personal concern.

${ }^{45} I d$. at $120-21$.

${ }^{46} \mathrm{Id}$. at 125 .

47 $I d$. (emphasis in original). 
Some times [sic] it is said that Man cannot be trusted with the government of himself. Can he, then, be trusted with the government of others? Or have we found angels in the forms of kings to govern him? Let History answer this question. ${ }^{48}$

489 The Works of Thomas Jefferson 196 (P. Ford ed. 1905). 